\title{
Economic-financial feasibility of pantaneiro lamb finishing systems
}

\author{
Leize Tatiane da Silva ${ }^{1}$ José Francisco dos Reis Neto $^{1^{*}}$ (-) Guilherme Cunha Malafaia ${ }^{1,2}$ \\ José Alexandre Agiova da Costa ${ }^{2}$
}

${ }^{1}$ Programa de Mestrado em Produção e Gestão Agroindustrial, Universidade Anhanguera Uniderp, Rua Alexandre Herculano, 1400, 79037280, Campo Grande, MS, Brasil. E-mail: jose.rneto@anhanguera.com."Corresponding author.

${ }^{2}$ EMBRAPA Gado de Corte, Campo Grande, MS, Brasil.

ABSTRACT: Technical and economic-financial performance of pantaneiro lamb finishing in feedlot $(F)$ and semi-feedlot $(S F)$ was evaluated. When analyzing the profitability, economic efficiency and the price sensitivity, was profit in all the scenarios evaluated. The gross margin (GM) was $69 \%$ and $52 \%$, net margin (NM) was $65 \%$ and $48 \%$ and profitability index (PI) was $39 \%$ and $29 \%$, as well as total productivity of factors (TPF) was $R \$ 1.53$ and $R \$ 1.36$, respectively, in the systems $F$ and SF. Investment analysis showed that the activity is economically viable, remunerating all production factors and capital invested. Internal return tax was, respectively, $27 \%$ and $16 \%$ for the in feedlot and semi-feedlot systems. Key words: production simulation; performance; sheep production; pantaneiro lamb, production systems.

Viabilidade econômico-financeira de sistemas de terminação de cordeiros pantaneiros

RESUMO: $O$ desempenho técnico e econômico-financeiro de sistemas de terminação de cordeiros pantaneiros em confinamento (C) e semiconfinamento (SC) foi avaliado. Ao se analisar a rentabilidade, a eficiência econômica e a sensibilidade dos preços, foi apurado lucro em todos os cenários avaliados. A margem bruta (MB) foi de 69\% e 52\%, a margem liquida (ML) foi de 65\% e $48 \%$ e o indice de lucratividade (IL) foi de 39\% e 29\%, bem como a produtividade total dos fatores (PTF) foi de R\$1,53 e R\$ 1,36, respectivamente, nos sistemas C e SC. A análise de investimento mostrou que a atividade é economicamente viável, remunerando todos os fatores de produção e o capital investido. A taxa interna de retorno foi, respectivamente, de $27 \%$ e $16 \%$ para a terminação em confinamento e semiconfinamento.

Palavras-chave: custos de produção; desempenho; ovinocultura; ovinos pantaneiros, sistemas de produção.

\section{INTRODUCTION}

The Midwest region has approximately $6 \%$ (1,1 million of heads), of the national flock of ovines (18,4 million of heads) (SOUZA et al., 2017). Among the states that comprise it, the state of Mato Grosso do Sul has great potential for meat production, due to its geographical location being close to the city's largest consumer which is São Paulo, the favorable climatic conditions and the possibility of production on a large scale. According to COSTA \& GONZALEZ (2012) the sheep farmer must seek the increase of zoothecnical indices, through the improvement of feeding, reproductive and sanitary management, in conditions that suit each system of production, by means of technological alternatives and management of greater technical and economic viability. Pantanal breed of sheep is in the process of registration, making important studies of economic and financial viability that may influence its use by sheep farmers. ORRICO (2015) studying the use of diets enriched with crude glycerin (7.5\%) instead of maize for Pantanal lambs, obtained an economic advantage with the substitution level, maintaining feedlot performance and carcass characteristics. ESPINOSA VILLAFUERTE (2016) studied finishing systems of Pantanal lambs. The highest cost of production was lamb acquisition (between 65 and 70\%), followed by feed cost (between 18 and 20\%). The highest profitability in the ILP system (semi-confinement: supplementation at $2 \%$ of the live weight in pasture of piatã grass + pigeon intercropped with maize for silage) with $30 \%$ to equal profitability in other systems with $27 \%$, the best result for the ILP system was due to lower costs of food, sanitation and opportunity cost. BATISTA et al. (2018), studying quantitative carcass characteristics and economic viability of Pantanal 
lambs finished in different production systems, obtained purchase costs of lambs ranging from 61 to $75 \%$ and feeding costs ranging from $14.5 \%$ to $26.8 \%$ total variable production costs. The ILP system (semiconfinement: supplementation at $2 \%$ of live weight in sorghum and piatã grass) was the most viable, as a result of the income received from the sale of grains.

However, the sheep chain is still little studied in the country. Focused on the production of meat and wool, it is concentrated in the Brazilian Northeast and South; although, the latter region has lost its representativeness. Economic feasibility study enerate information that subsidize the creation of new races, in the case of the Pantanal races, is of fundamental importance to guide the decision-making process of rural producers. The present study aimed to evaluate economic and financial performance of systems of lambs' termination in feedlot (F) and semi-feedlot (SF), in order to offer the sheep farmer alternatives of production economically viable.

\section{MATERIALS AND METHODS}

Experiments were performed in the Model Farm of Beef Cattle of Embrapa, at the Midwest Embrapa Center of Goats and Sheep, in Terenos/MS, geographic coordinates $20^{\circ} 55^{\prime} 34^{\prime \prime} \mathrm{S}$ and $54^{\circ} 81^{\prime} 24^{\prime} \mathrm{W}$, altitude of $532 \mathrm{~m}$. were considered for the financial and economic analyzes and zootechnical performance of years 2011 and 2012, in the following finishing systems:

-Feedlot (F) -50 Pantaneiro lambs finished with sorghum silage based diet, provided $a d$ libitum and energetic-protein concentrate, based on corn and soybeans meal (15\% CP and 70\% TDN), limited to a daily supply of $2 \%$ of body weight;

-Semi-Feedlot (SF) -50 Pantaneiro lambs finished on piatã-grass pasture (Brachiaria brizantha $\mathrm{cv}$ Piatã), deferred grazing for six months to lamb use in the alternated pasture system, supplemented at $2 \%$ of body weight, with the same concentration of feedlot system.

Pantaneiro origin lambs were weaned at 75 days and slaughtered in 2011 at 63 experimental days when they reached the average weight of $26.7 \mathrm{~kg}$ and in 2012, at 70 days of experiment, with $26.22 \mathrm{~kg}$. At the system $\mathrm{F}$ a $200 \mathrm{~m}^{2}$ shelter with concrete floor, with space of $2 \mathrm{~m}^{2}$ per animal, and in the system SF a 1.2ha of pasture formed with piatã-grass was used.

Calculation sheets were assembled with the data of zootechnical performance resulting from the experiments and the prices adjusted for the date of March 2018 (US\$1.00= R\$3.30). Property inventories (machinery, equipment and facilities) were prepared according to the methodology described by VIANA
\& SILVEIRA (2008). For the economic and financial analysis, spreadsheets in the program excel were elaborated. The calculation of cost of production followed the methodology of CAMPOS (2003), separating the effective operational cost (EOC), the total operational cost (TOC) and the total cost (TC). Therefore, it will be deemed as EOC the direct expenditures of the activity that, in its majority, vary directly with the increase or decrease in production, such as food, sanity, workforce, among others. The COT was composed by EOC added of depreciations with machines, equipment and facilities. The CT was obtained by adding value of the remuneration of capital invested and the opportunity cost of land in COT.

Lambs forfinishing systemswere evaluated in $\mathrm{R} \$ 5.50$ average live weight and the selling prices for the calculation of revenue were established based on those practiced in the region of Campo Grande of $\mathrm{R} \$ 7,30$ per kilo/live weight (CEPEA, 2018).

To calculate the opportunity cost, which is the minimum that the farmer loses out on earning in another activity to invest in sheep farming, a minimum rate of attractiveness of $6 \%$ per year was determined (real interest rate of savings accounts).

The method used in the depreciation calculation of the fixed capital was fixed quotas (or linear), with a residual value of $10 \%$, in what is considered the new value minus the residual value and divided by the life span (HIRSFHFELD, 2000). It was considered the value of R\$ 9.583 in the acquisition of the hectare of land. Out of the rate $7.95 \%$ a year (real rate of interest on savings accounts) $3 \%$ of real appreciation of the land have been discounted (CANZIANI \& GUIMARÃES, 2009).

The indicators of profitability calculated were the rate of return (TR), gross margin (GM), net margin (NM), profitability index (PI) and Profit (P) or net income (NI), according to methodology used by CAMPOS(2003).

For the indicators of economic efficiency, the following were analyzed: The total productivity of the factors (TPF), rateofreturn(TR), pointof equilibrium(PN) and family income, according to MARTINS et. al (2012).

For sensitivity analysis, which considers limits the price of the live weight lamb can vary without compromising economic feasibility of production systems, prices at three unfavorable levels were considered $\{-10 \%,-20 \%,-30 \%\}$ and at three favorable levels too $\{+10 \%,+20 \%,+30 \%\}$.

At the production simulation, aiming to increase the productive capacity with the existing infrastructure, the capacity of termination was increased. It was considered the area of $0.5 \mathrm{~m}^{2}$ per lamb (CAVALCANTE et al., 2005) to the feedlot (F) and the pasture area for $6 \mathrm{~h}$ in semi-feedlot (SF). 
Four cycles of production in the System F were adopted, finishing of 500 lambs in each, totaling 2,000 lambs/ year. In the SF, system, three cycles were considered, two cycles of 500 lambs in each during the rainy season, and a cycle of 250 lambs during the dry period, totaling 1,250 lambs/year. Labor costs, for simulation purposes, were prorated by the number of hours worked annually, being proportional to the production costs, by the productivity in live weight obtained in each termination cycle, being considered that a worker has conditions of also produce lots of 250 or 500 lambs.

Cash flow was performed for ten years. The cash inflows were composed of rate of return (selling of live weight lambs) and residual value of investment. The cash outflows considered the initial investment (facilities, machinery and equipment, land) and working capital (GUIDUCCI et.al., 2012). From the year 1 to 9, the nominal balance was obtained by subtracting EOC (expenditure) from RT (receipt). Nominal balance was corrected year to year by the interest rate of $6 \%$. In the $10^{\text {th }}$ year of the project, it was added the sales revenue of live weight lambs and the residual value of the investment, and EOC was subtracted from this value.

From the cash flow, three indicators of economic viability were considered: net present value (NPV), internal rate of return (IRR) and the capital return period (Payback), where:

a) $\mathrm{NPV}=$ a value at the moment considered initial (sum of the balances of cash flow), being discounted MRA (minimum rate of attractiveness) of $6 \%$, adopted by the research. The investment is only feasible if NPV is higher than zero.

$N P V=-I I+\sum_{i}^{n}=1 \frac{a_{i}}{(1+M R A)^{i}}$

where: $\mathrm{II}=$ initial investment in the period 0 ; $a_{i}=$ income flow in the period $\mathrm{i} ; \mathrm{MRA}=$ minimum rate of attractiveness; $i=$ period, where $i=1,2 \ldots, i$.

b) $\mathrm{IRR}=$ annual rate $(\%)$ of return on invested capital. Investment is feasible if IRR is higher than MRA.

c)Period of capital return $($ Payback $)=$ period (years) so that the farmer recovers the capital invested (Investment/Annual income).

\section{RESULTS AND DISCUSSION}

The zootechnical performance was similar between the systems. (Table 1). The weight gain in feedlot was $10.84 \mathrm{~kg}$ and in semi-feedlot $10.46 \mathrm{~kg}$. Slaughter weight was, respectively, $26.60 \mathrm{~kg}$ and $26.33 \mathrm{~kg}$, for $\mathrm{F}$ and SF. Carcass yield was $45 \%$, the same between the finishing systems. The lambs were slaughtered aged 143 days at the average.
Table 1 - Productive results obtained in the Experimental Finishing Systems with 50 lambs.

\begin{tabular}{lcc}
\hline Termination system & Feedlot & $\begin{array}{c}\text { Semi- } \\
\text { feedlot }\end{array}$ \\
Average initial live weight (kg) & 15.76 & 15.87 \\
Average live weight at slaughter (kg) & 26.60 & 26.33 \\
Daily average weight (g) & 163.17 & 157.43 \\
Number of finishing days & 67 & 67 \\
Carcass yield (\%) & 45 & 45 \\
Carcass hot weight (kg) & 11.97 & 11.85 \\
Lambs mortality (\%) & 0 & 2 \\
Slaughtered animals (heads) & 50 & 49 \\
Carcass total (kg) & 598 & 574 \\
Live weight total (kg) & 1,330 & 1,276 \\
\hline
\end{tabular}

Legend: ${ }^{*}$ Mortality by photosensitization. (SOURCE: Experimental data).

The data generated from the research (Table 1) allowed to define the information for the simulation of economic feasibility of the activity. The number of animals slaughtered in feedlot is $60 \%$ higher than in pasture. In this scenario, the total cost to terminate 2,000 lambs in F was R\$ 265,819 and to terminate 1,250 lambs in SF was R\$169,827. A total cost over $57 \%$ for the feedlot.

Detailing of the production costs of finishing systems of lambs is reported in table 2 . Of all the aggregate factors, the item that burdened the production system the most was the cost of lamb acquisition, which happened with ESPINOSA VILLAFUERTE (2016) e BATISTA et al. ( 2018), that represented $65.2 \%$ in $\mathrm{F}$ and $64.2 \%$ in SF. The second item that burdened $\mathrm{F}$ the most was feeding with $13.7 \%$, and with $10.2 \%$ in SF. The third was the work force in SF with $10.5 \%$, due to the lower number of finished lambs. Lambs' finishing analysis in $\mathrm{F}$ and the pasture performed by BARROS et al. (2009) indicated, respectively, the feeding, with $33.4 \%$ and $10.7 \%$, and the workforce, with $33.4 \%$ and $10.7 \%$ as items that most influenced the effective operational cost. Depreciation and sanity presented values very close, other costs (fuel, energy, telephone) maintenance and conservation have the highest percentages in $\mathrm{F}$ than in SF.

Analyzing the indicators of profitability of the lambs' finishing system, the revenue obtained was higher in system F, value of $\mathrm{R} \$ 388,307.04$, higher 
Table 2 - Comparative of annual costs of lamb finishing system, with $2 \%$ of feeding supplementation.

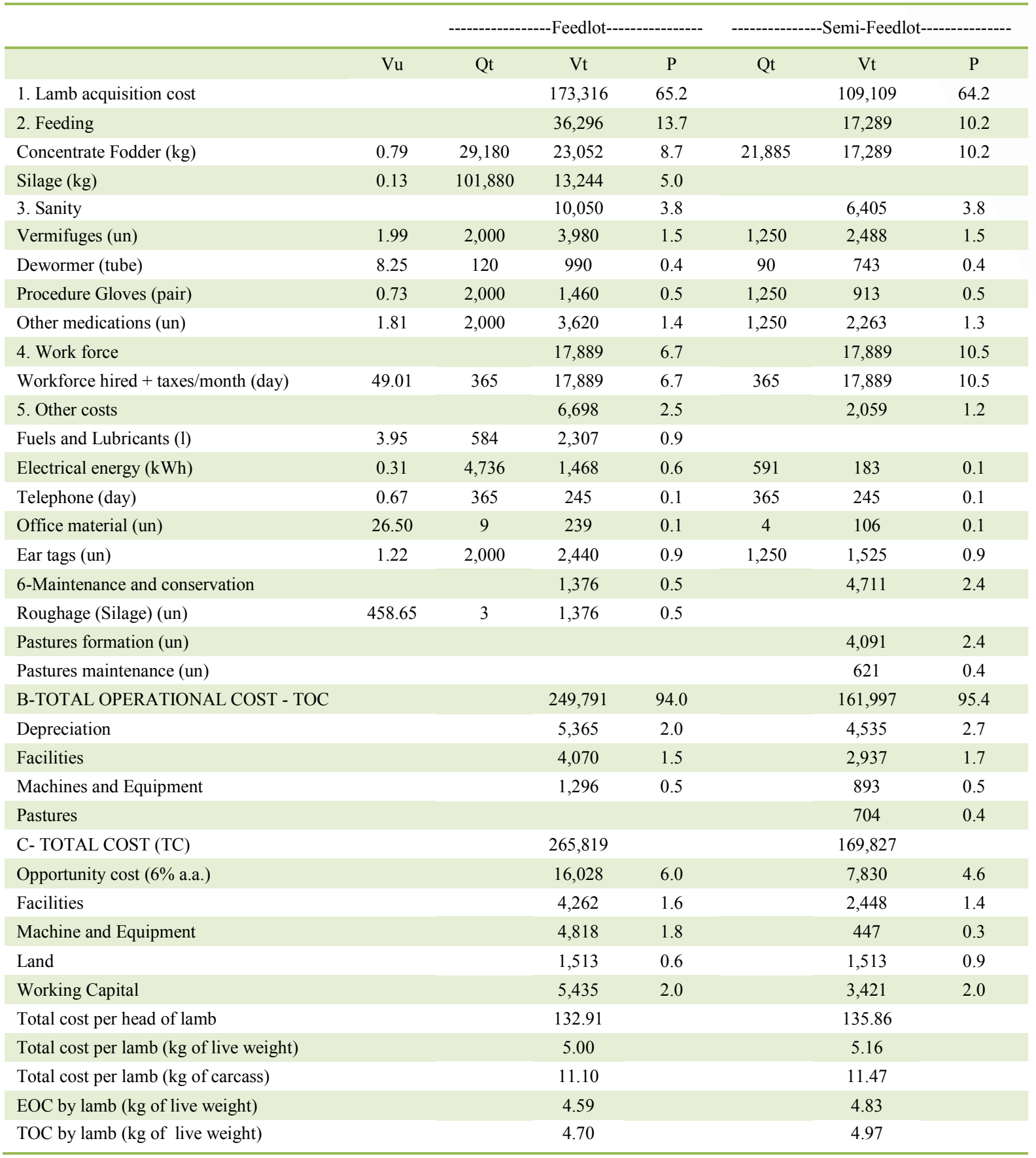

Legend: un - units; Qt - quantity; Vu - unit value, in R\$; Vt - total value, in R\$; P - Relative Participation, in \%; Note: US\$1.00 $=$ R\$3.30 in March 2018.

than in SF, with revenue of $\mathrm{R} \$ 237,836.95$. Gross margin (GM) is positive in both systems. This showed that the rate of return (TR) is higher than the effective operational cost (EOC). In the short run, the farmer will be able to remain in the activity, since that it is verified positive GM, sufficient to remunerate the fixed costs. In percentages, 
GM was $59 \%$ in $\mathrm{F}$ and $51 \%$ in SF. The net margin (NM) was positive in both systems. This means that the producer may remain in the activity in the long run, TR is higher than TOC, in percentages, NM was $55 \%$ and $47 \%$.

The profitability index (PI), therefore, was positive in both systems, which showed the relationship between the NM and the TR in percentage available in the activity, after the payment of TOC. The lowest profitability was $30 \%$ in SF, in both systems the producer may remain in the activity in the long run. The highest profit was obtained in F, $\mathrm{R} \$ 2.30$ per $\mathrm{kg} /$ live weight, and in pasture was $\mathrm{R} \$$ 2,14 per $\mathrm{kg} / \mathrm{live}$ weight. The profit per $\mathrm{kg} / \mathrm{live}$ weight in $\mathrm{F}$ is $7 \%$ higher compared to the pasture. The profit per live weight lamb (head) in F was $\mathrm{R} \$ 61.24$ and in SF R $\$ 56.38$, the fall of the total cost per head in $F$ is $9 \%$ compared to SF.

The equilibrium point, indicated the quantity of product necessary to cover all production costs, allowing the stability in the production systems analyzed which is 1,369 and 884 heads, respectively for $\mathrm{F}$ and SF. Below the level of production of 36,414 and $22,778 \mathrm{~kg}$, the net income generated would be negative, which would make the production systems economically unfeasible. The total productivity of factors (TPF) was R\$ 1.46 and $\mathrm{R} \$ 1.40$, to $\mathrm{F}$ and $\mathrm{SF}$, which indicated that the production systems are profitable and efficient, since that the greater a TPF, the better the profitability of investment (Table 3 ).

Return rate (TR) was also higher in the systems analyzed of $0.46 \%$ in $\mathrm{F}$ and $0.40 \%$ in SF. This means that, for each $\mathrm{R} \$ 1.00$ spent in $\mathrm{F}$, it was generated R \$ 0.46 of net income, which in SF, it was generated R\$ 0.40 . Also, family income is higher in $83 \%$ in F compared to SF. For each working month, the farmer monthly income in $\mathrm{F}$ was de $\mathrm{R} \$ 11,543$ and in SF was R \$ 6,320.

The sensitivity analysis practiced in the research enabled to identify the limits of the price of lamb live weight that cause changes in indicators of economic efficiency of production systems. It was considered the range of $-30 \%$ up to $+30 \%$ of its original values that is $\mathrm{R} \$ 7.30$, at intervals of variation, upwards or downwards, to $10 \%$. The net income (NI) was positive in all the scenario evaluated not only in F but also in SF as indicated in table 3.

When it comes to investment return, an internal rate of return (IRR) of 33\% was obtained for $\mathrm{F}$ and one of $30 \%$ for SF. The IRR indicated the economical-financial feasibility of the systems, higher than MRA of $6 \%$ a year, the minimum desired for the negotiation. The IRR reached, a value greater than zero, indicated the economic-financial feasibility of the system, i.e., in addition to achieving the minimum expected (MRA on the value of $6 \%$ ), a result in surplus money was obtained in feedlot equivalent to $\mathrm{R} \$ 921,238.17$ and in the pasture $\mathrm{R} \$ 406,051.67$. This indicated that the system allows the farmer to recover the capital invested within 10 years. The period of return on investment measured in relation to the business time, showed that the total return of initial investment, for the system recommended by the study, will occur in 4 years, in $\mathrm{F}$ and 5 years in SF.

\section{CONCLUSION}

The analysis of economic and financial indicators of production systems showed positive values, demonstrating the financial viability of the termination systems in F and SF (supplementation on pasture). The two production systems showed profitability and economic efficiency in production conditions.

The costs of production of both production systems are burdened mainly by the cost of acquisition of the lambs. The own creation of lambs and the use of specialized race in meat production may decrease the production costs.

The investment analysis shows that the activity is economically viable, paying all the factors of production and the invested capital, the internal rate of return above the minimum rate of business attractiveness.

The factor which must be highlighted when it comes the results observation is the profitability increase in scale production. The higher the lambs' production, the more diluted is the production cost, which positively impacts on the profit and the family's monthly income. Thus, when increases in production are simulated, considered the existing infrastructure, lambs' termination of in feedlot had higher economic returns than the system in pasture.

It was verified that the time of return on investment occurred in the four years for $\mathrm{F}$ and the five years for SF for both the finishing systems, using the maximum production capacity of each system, in annual finishing cycles.

Finally, the research presents some limitations, that is, the characteristic of the experiment that precludes a large-scale analysis of Pantanal lamb finishing systems; however, it offers technical data that allow to carry out the simulation. It is known that the simulation method may present distortions that do not fully capture the real conditions of a tax system, while providing subsidies for a plantain at the level of a commercial productive unit. 
Table 3 - Analysis of Economical Sensitivity of the Lamb Finishing Systems.

\begin{tabular}{|c|c|c|c|c|c|c|c|}
\hline \multirow[b]{2}{*}{ Sensitivity } & \multicolumn{3}{|c|}{----------Less favorable (\%) --------- } & \multirow{2}{*}{$\begin{array}{c}\text { Neutral (\%) } \\
0\end{array}$} & \multicolumn{3}{|c|}{----------More favorable $(\%)$--------- } \\
\hline & -30 & -20 & -10 & & 10 & 20 & 30 \\
\hline Price of $\mathrm{kg}$ live weight $(\mathrm{R} \$$ ) & 5.11 & 5.84 & 6.57 & 7.30 & 8.03 & 8.76 & 9.49 \\
\hline \multicolumn{8}{|l|}{ Feedlot } \\
\hline Net Profit (R\$) & 5,996 & 44,827 & 83,657 & 122,488 & 161,319 & 200,149 & 238,980 \\
\hline Equilibrium point (Heads) & 1,956 & 1,711 & 1,521 & 1,369 & 1,245 & 1,141 & 1,053 \\
\hline Equilibrium point (kg) & 52,476 & 45,067 & 40,460 & 36,414 & 33,103 & 30,044 & 28,256 \\
\hline Total productivity of the factors (TPF) & 1.31 & 1.17 & 1.02 & 1.46 & 1.61 & 1.75 & 1.90 \\
\hline Rate of return (TR) (\%) & 0.02 & 0.17 & 0.31 & 0.46 & 0.61 & 0.75 & 0.90 \\
\hline Family income $(\mathrm{R} \$)$ & 22,024 & 60,854 & 99,685 & 138,516 & 177,347 & 216,177 & 255,008 \\
\hline Monthly family income (R\$) & 1,835 & 5,071 & 8,307 & 11,543 & 14,779 & 18,015 & 21,251 \\
\hline \multicolumn{8}{|l|}{ Semi-feedlot } \\
\hline Net Profit (R\$) & $-3,341$ & 20,443 & 44,227 & 68,010 & 91,794 & 115,578 & 139,361 \\
\hline Equilibrium point (Heads) & 1,238 & 1,083 & 963 & 866 & 788 & 722 & 666 \\
\hline Equilibrium point (kg) & 31,703 & 28,369 & 25,320 & 22,788 & 20,716 & 18,912 & 17,071 \\
\hline Total productivity of the factors (TPF) & 0.98 & 1.12 & 1.26 & 1.40 & 1.54 & 1.68 & 1.82 \\
\hline Rate of return (TR) $(\%)$ & -0.02 & 0.12 & 0.26 & 0.40 & 0.54 & 0.68 & 0.82 \\
\hline Family income (R\$) & 4,489 & 28,273 & 52,056 & 75,840 & 99,624 & 123,408 & 147,191 \\
\hline Monthly family income (R\$) & 374 & 2,356 & 4,338 & 6,320 & 8,302 & 10,284 & 12,266 \\
\hline
\end{tabular}

Note: US\$1.00 = R \$3,30 in March 2018.

\section{BIOETHICS \\ AND \\ BIOSSECURITY}

We authors of the article entitled "Economicfinancial feasibility of lamb finishing systems" declared, for all due purposes, the project that gave rise to the present data of the same has not been submitted for evaluation to the Ethics Committee of the Universidade Anhanguera (Uniderp), but we are aware of the content of the Brazilian resolutions of the National Council for Control of Animal Experimentation CONCEA if it involves animals. Thus, the authors assume full responsibility for the presented data and are available for possible questions, should they be required by the competent authorities.

\section{ACKNOWLEDGEMENTS}

The authors would like to thank the Univerdiade Anhanguera (Uniderp) for financial support, and to the EMBRAPA Gado de Corte, Campo Grande, MS, Brasil, for assignment of researchers and facilities.

\section{DECLARATION OF CONFLICT OF INTEREST}

The authors declare no conflict of interest. The founding sponsors had no role in the design of the study; in the collection, analyses, or interpretation of data; in the writing of the manuscript, and in the decision to publish results.

\section{REFERENCES}

BARROS, C.S. et al. Resultado econômico da produção de ovinos para carne em pasto de azevém e confinamento. Acta Scientiarum. Animal Sciences, v. 31, n. 1, p.77-85. 2009. Available from: $<$ http:// www.redalyc.org/articulo.oa?id=303126495005>. Accessed: 20 Mar. 2014. doi: 10.4025/actascianimsci.v31i1.3995.

BATISTA, N. J. M. et al. Bioeconomic efficiency of lamb finishing production systems. SEMINA Ciência Agrárias, v. 39, n. 3. 2018 [no prelo].

CAMPOS, R.T. Tipologia dos produtores de Ovinos e Caprinos do Estado do Ceará. Revista Econômica do Nordeste, v.34, n.1, p.85112, 2003. Available from: <http://www.repositorio.ufc.br/handle/ riufc/1161>. Accessed: 12 May. 2014.

CANZIANI, J.R.F.; GUIMARÃES, V. A. O cálculo e a análise do custo total de produção de produtos agrícolas para fins de gerenciamento e tomada de decisão. Exemplos para a cana-deaçúcar. Universidade Federal do Paraná: Departamento de Economia Rural e Extensão, jul. 2009. Available from: <http://www.ebah.com. br/content/ABAAAAam8AC/teoria-custo-total-cana\#>. Accessed: 03 Sep. 2013.

CENTRO DE ESTUDOS EM ECONOMIA APLICADA (CEPEA). Preços Dos Cordeiros Cepea/Esalq - Quilo Vivo. Available from: <https://www.cepea.esalq.usp.br/br/indicador/ovinos.aspx.>. Accessed: 05 Apr. 2018.

COSTA, J.A.A.; GONZALEZ, CIM. Produção de Ovinos de Corte em Sistemas de Integração. In: BUNGENSTAB, D.J. Sistema de 
integração lavoura-pecuária-floresta: a produção sustentável. Brasília: Embrapa, 2012. Cap.13, p.189-198.

CAVAlCANTE, A.C.R. et al. Caprinos e Ovinos de Corte para o Nordeste Brasileiro. Sistemas de Produção. Sobral: Embrapa Caprinos e Ovinos. Versão eletrônica, dez. 2005. Available from: $<$ https://www.agencia.cnptia.embrapa.br/gestor/territorio sisal/ arvore/CONT000fckg3dhc02wx5eo0a2ndxyyaotzbb.ht $\overline{M N}>$. Accessed: 12 May. 2014.

ESPINOSA VILLA FUERTE, S.G. Sistemas de terminação de cordeiros do grupo gnético Pantaneito, 2016. 51 f. Goiania, Go: UFG. Dissertação de mestrado, 2016. Available from: $<$ https://repositorio. bc.ufg.br/tede/bitstream/tede/5702/5/Disserta\%c3\%a7\%c3\%a3o $\% 20$ -\%20Sergio\%20Giovanni\%20Espinosa $\% 20$ Villafuerte $\% 20-\% 20$ 2016.pdf>. Accessed: 04 Apr. 2018.

GUIDUCCI, R.C.N. et al. Aspectos metodológicos da análise de viabilidade econômica de sistemas de produção. In: GUIDUCCI, R.C.N.; LIMA FILHO, J.R.; MOTA, M.M. Viabilidade econômica de sistemas de produção agropecuários: metodologia e estudos de caso. Brasília: Embrapa, 2012. Cap.1, p.17-78.

HIRSFHFELD, H. Engenharia Econômica e Análise de Custos: aplicações práticas para economistas, engenheiros, analistas de investimentos e administradores. 7.ed. São Paulo: Atlas, 2000. 465p.
MARTINS, E.C. et al Sistemas e custos de produção de ovinos de corte na agricultura familiar no Ceará. In: GUIDUCCI, R.C.N.; LIMAFILHO, J.R.; MOTA, M.M. Viabilidade econômica de sistemas de produção agropecuários: metodologia e estudos de caso. Brasília: Embrapa, 2012. Cap.2, p.117-121.

ORRICO, M.A.P. Crude glycerin in the diets of confined lambs:performance, carcass traits and economic feseability. Biosci. J., Uberlândia, v. 31, n. 4, p. 1152-1158. 2015. Available from: $<$ http://www. seer.ufu.br/index.php/biosciencejournal/article/view/26226/16736>. Accessed: 04 Apr. 2018

SOUZA, J. D. F et al. Evolução do rebanho ovino entre 2007 e 2016. Sobral, CE: Embrapa Caprinos e Ovinos, 2017. 14p. (Boletim do Centro de Inteligência e Mercado de Caprinos e Ovinos n.1, (out. 2017). Available from: <https://ainfo.cnptia.embrapa.br/digital/ bitstream/item/165640/1/CNPC-2017-Boletim-CIM.n1.pdf>. Acessed: 02 Apr. 2018.

VIANA, J. G. A.; SILVEIRA, V. C. P. Análise econômica e custos de Produção aplicados aos sistemas de produção de ovinos. In: CONGRESSO DA SOCIEDADE BRASILEIRA DE ECONOMIA, ADMINISTRAÇÃO E SOCIOLOGIA RURAL, 46, 2008, Rio Branco. Anais eletrônicos, Brasília: SOBER, 2008. Available from: <http://ageconsearch.umn.edu/bitstream/109525/2/628.pdf>. Accessed: 20 Mar. 2014 